TURIZAM

Volume 18 , Issue 2

72-83 (2014)

\title{
Wellness Centers in Slovenia: Tourists' Profiles and Motivational Factors
}

\author{
Milica Rančić, Lazar Pavić*, Maja Mijatov* \\ Received: November 2013 | Accepted: March 2014
}

\begin{abstract}
Wellness and spa tourism has increasingly become an important economic and marketing strategy for hoteliers, resorts and tourist destinations to attract tourist visitations. Deep understanding of consumer profiles and their key motivations within this context is vital in order to sustain the growth of wellness and spa tourism business. This paper presents an exploratory study that seeks to understand the spa and wellness tourists' motivation during their visits to spa and wellness service centers in Slovenia. The purpose of this research is to examine the characteristics of a healthy-living market segment and its motivational behavior to wellness facilities in Slovenia. The paper provides the broad understanding of wellness and spa tourists' profiles in Slovenia and the key motivation factors.
\end{abstract}

Key words: wellness and spa tourism, motivation factors, tourst lifestyle, the hotel's wellness center, Slovenia

\section{Introduction}

Over the past centuries, spa and wellness-oriented activities have been recognized around the world with existing of different health practices of the people in different regions for staying healthy and for healing/curing remedies as well. The development of wellness tourism can be resonated with the echoes of the great economic growth and major demographic shift occurring in most countries across the globe.

McNeil and Ragins (2004) suggested that spa participation is currently showing incredible growth, as more consumers turn to spa facilities as venues to improve their health and well-being. Although it is luxury, it is seen as much more necessity, and factors like personal space, time out, escapism, retreats contribute to spa visitation. Hotel guests, today more than ever, want higher quality offer for their money (Blešić et al., 2008). This means that wellness is today a very important criterion by which customers select hotels. However, different people have different motivations for coming to the wellness center, some of them have health motives, and some of them do that because of relaxation, recreation etc...

* Department of geography, tourism and hotel management, Faculty of Sciences, University of Novi Sad, Trg Dositeja Obradovića 3, 21000 Novi Sad, Serbia; milicarancic@hotmail.com 
Though wellness and spa tourism has longevity in historical terms, this type of tourism can be considered at its infant stage, at which health and spa tourists' motivation remains a substantive interest for researches. There is generally lack of empirical studies on health and spa tourism motivation in understanding the fundamental needs of the health and spa goers during holiday, as there is a growing concern on health among the population at present. Anyway, as in other types of tourism, it is important to emphasize that knowing the motives of visitors results in ability to increase visitors' enjoyment; moreover, it makes it possible to attract and retain more visitors (Blešić et al., 2OI3).

The survey was conducted in Slovenia, which was chosen as a well-developed wellness tourism destination due to its traditional thermal baths and the modern wellness centers.

\section{Wellness tourism}

The term „wellness“ was coined during the I950s in the US by those in health sciences and medical sociology (Ritter, 2005). They merged words „well-being“ and „fitness“ to create „wellness“. This term has been described as an individual, multi-faceted, interdisciplinary expression for the human need for health and well-being. Puczk and Bachvarov (2006) stated that wellness is supposed to create harmony in mental, physical, spiritual, and biological health in general; it has stronger ties with changing lifestyle or doing something healthy than with curing a particular disease, or ailment.

Wellness tourism is the sum of all the relationships and phenomena resulting from a journey and residence by people whose main motive is to preserve or promote their health (Muller, Kaufmann, 2OOI). Health care tourism encompasses both wellness tourism and medical tourism and is thus on the top tier, while medical tourism and wellness tourism are both on the second tier (Mugomba, Caballero, 2006). Likewise, wellness tourism is a sub-sector of health care tourism, although unlike medical tourism, wellness tourism doesn't include elective surgery. Wellness tourism deals with healthy people who care about health and fitness and focus on more preventive activities during journey. However it is often hard to divide the categories of health care tourism, medical tourism and wellness tourism, because it is easy for destinations of healthcare, medical, and wellness tourism to provide similar healthy services such as massage, yoga practice, spa and healthy foods.

\section{The Wellness Tourism in Slovenia}

The great diversity of landscapes and the easy availability of the country, Slovenia influences the fact that this country has the opportunity to develop a different type of tourism (Ažman Momirski, Kladik, 2009). One of the most developed is the spa tourism, especially modern form of the wellness tourism. The Wellness and spa programs in the Slovenian spas have become liabilities, and the spa tourism in Slovenia can serve as a unique example of the mutual complement of the health spas and the tourist functions. There is a combination of tradition, a very long experience and discoveries of the modern professionals.

Slovenia is a small country, but it is full of natural resources: there are some healing thermal waters and the good climate conditions. There are some thermal waters with different properties and temperature (from 32 to 73 degrees Celsius) and some mineral water (world famous "Donat Mg" and "Radenska Three Hearts"), and also the salt water, some organic and inorganic peloids. The climate is maritime, Pannonian and subalpine. In fifteen spa 
centers with the motto "With the nature to the health" the latest offerings are developed in the field of "wellness" and some new programs for the health care and the disease prevention as well. When it comes to the spa tourism, Slovenia is the most competitive country among the countries of the former Yugoslavia.

\section{Literature Review}

The study of motivation is being widely used in understanding of the human behaviour and can be found in the literature of many disciplines. Likewise in tourism, the concept of the motivation has been used in understanding tourist behaviours and their travel decision-making, which can be indicative to the tourism providers to attract tourists and meet their needs during their travel at a particular destination. Page and Connell (2006) stated that motivation as a subject was an integral part of the study of consumer behaviour in tourism.

Among the most well-known tourist motivation theory is the „push-pull“ concept in which activity is seen as a product of a pull-push relationship. The idea of the push-pull model is the decomposition of a tourist's choice of destination into two forces, which are push and pull factors (Bansal, Eiselt, 20O4). The push factors are considered to be socio-psychological motivations that predispose an individual to travel, while the pull factors are those that attract an individual to a destination once the decision to travel has been made (Kim, Lee, 20O2).

Yoon and Uysal (2005) stated that push motivations were more related to the internal emotional aspects, while pull motivations were connected to the external, the situational, or the cognitive aspects.

This concept was also applied in the study of tourist motivation in the field of wellness tourism. It was concluded that there must be the factors that motivate tourists to use the spa services, but also the real attributes that attract them to come to a spa facility. Based on this concept, the research was carried out in Malaysia. The Authors Azman and Chan (2OIO) wanted to investigate the motivation of wellness tourists in this area. Data were collected through the in-depth interview and it is concluded that the motivation of wellness tourists largely depends on the personal needs and the lifestyle, and then on the price and quality of services.

One of the available researches that is directly linked to the health and spa goers is of Mak and Wong (2007), who examined the underlying factors that motivate Hong Kong travelers to search for spa experiences. The structured questionnaires were employed to conduct the survey and received a total of $3 \mathrm{O} 2$ responses. The motivation factors: the relaxation and the relief, the escape, the self-reward and indulgence, and health and beauty are the most important factors that motivate the travelers to visit spas.

On the contrary, there are studies integrating healthy lifestyle into consumer/tourists behaviours by Gonzalez and Bello (2002) show a strong dependency relationship between tourists' behaviours on the trip and the lifestyle. Based on that, Byung hun Kim and Adarsh Batra (2009) suggest a hypothetical model that examines and finds a relationship between the healthy lifestyle of wellness tourists and their motivations in the wellness center. This model consists of the two main parts. The first section relates to a healthy lifestyle and it consists of six variables (exercise, diet, alcohol and drugs, smoking, stress, safety) contained in I8 questions. The second section evaluated the motivational behavior and contains thirteen questions. Based on this model, a study was explored by I64 questionnaires at the eight well- 
ness centers of hotels in Bangkok from February to April in 2009. It maintains that recreation, relaxation, enhancement of the quality of life and some social activities are the top four motivational factors when visiting wellness facilities. The correlation results revealed that there were relationships between the healthy-living behavior statuses with the regard to a diet, a smoking status, and the safety and motivational behavior to visit wellness facilities.

\section{Methodology}

\section{The Model for Measuring Motives of the Wellness Users}

The model described in the previous chapter that was used in Thailand is also used for this research. The first part of the questionnaire relates to the socio-demographic data: gender, age, education, occupation, the place of residence, the amount of monthly income.

The second part of the questionnaire refers to the issues of healthy living habits. This part consists of the 6 variables, or I8 questions from the model taken over by the Thai authors Byung hun Kim and Adarsh Batra (2009).The variables (exercise, diet, alcohol and drugs, smoking, stress and safety) were measured using the multi-items measures. Each item contains a five-point Likert scale on which the respondents declared themselves to what extent they abide the guidelines of a healthy lifestyle: I - never, 2 - rarely, 3 - sometimes, 4 - often, 5 - always.

The third part of the questionnaire refers to the importance of the guest's motives in the wellness center. This part, as the second part of the questionnaire, is also taken from the aforementioned model by Thai authors Kim and Batra (2009) and consists of I3 motivational factors. In this section a five-point Likert scale is used, in which the respondents had to declare how important some motive for coming to the wellness center is: I - not important at all, 2 - not important, 3 - neither or nor important, 4 - fairy important, 5 - very important.

\section{The Hypotheses}

HI: The people from Slovenia (and from the other countries of the western Europe in general) have more developed habit of visiting wellness centers because of the more frequent wellness philosophy, therefore they very often visit these places.

H2: The primary reason for visiting depends on the type of the hotel in which the wellness center is. Accordingly, the guests who come to the spa hotels visit the wellness centers because of the health improvement. On the other hand, those who come to the city hotels, they do it mostly because of the relaxation and rest.

H3: Younger persons are more interested in "the active holiday", that is why the recreation is more important reason for them for visiting a wellness center than for the others guests of different age.

H4: The business people are under bigger stress than the other groups in the survey, which is why the mental therapy and the meditation are reasons that are more important for them for visiting a wellness center than to the others. 


\section{Findings and Discussion}

\section{The Data Analysis}

The research was carried out from April to July 20I3. The study involved the service users in the wellness centers of some selected hotels in Slovenia. The research was conducted on the entire territory of Slovenia and the wellness centers were chosen on a random basis (Table I). During the questioning, the I2O questionnaires were distributed, but in the end, there were IOO valid questionnaires (83\%).

Table 1. List of hotels

\begin{tabular}{|l|c|c|c|}
\hline Hotel name & Category & Tipe of hotel & Location \\
\hline Park & $4^{*}$ & spa hotel & Laško \\
\hline Lipa & $3^{*}$ & spa hotel & Lendava \\
\hline G.H.Sava & $4^{*}$ & spa hotel & Rogaška Slatina \\
\hline Bolfenk & $4^{*}$ & mountain hotel & Mariborsko Pohorje \\
\hline Habakuk & $5^{*}$ & mountain hotel & Mariborsko Pohorje \\
\hline Larix & $4^{*}$ & mountain hotel & Kranjska Gora \\
\hline Austia trend & $4^{*}$ & city hotel & Ljubljana \\
\hline Betnava & $4^{*}$ & city hotel & Maribor \\
\hline G.H.Portorož & $5^{*}$ & beach hotel & Portorož \\
\hline Slovenija & $4^{*}$ & beach hotel & Portorož \\
\hline
\end{tabular}

The graph I shows the frequency of visiting the wellness centers by the service users on the weekly, monthly and yearly bases. The biggest percent of the service users, almost $30 \%$, answer that they visit the wellness centers once in a month. The similar percentage, about one third, belongs to the group who visits the wellness centers once or twice a year. Almost one fifth, i.e. I9\% surely visits some of the wellness centers once in a week, and there are those people, about $5 \%$, who visit the wellness centers even three times a week. These data show that the visitors of the wellness centers in Slovenia have relatively well developed habit of using the wellness services, which is not odd because of their standard, the western life

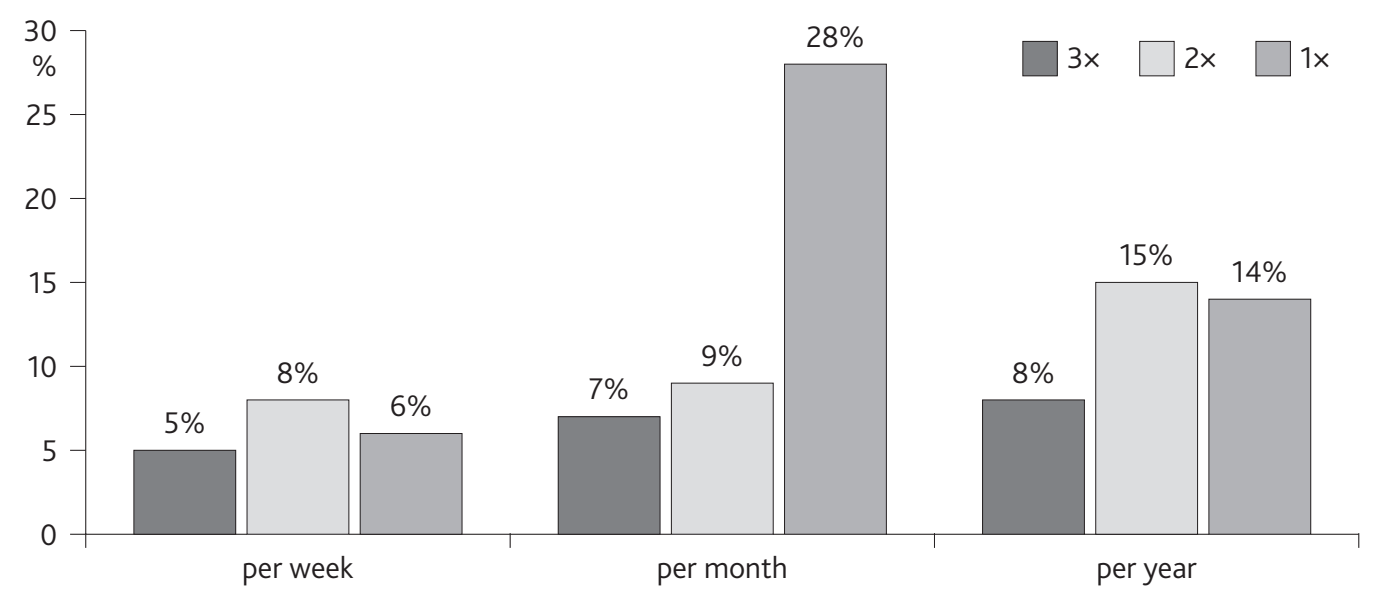

Graph 1. The frequency of visiting the wellness centers 
style and also because of the fact that there are many wellness centers in a small territory of their country. It should be also said that their medical system invests many efforts into spreading the wellness philosophy, especially through the mission of the public medical network of the health resorts in Slovenia. All these facts confirm the hypothesis I.

Table 2 shows that the primary reason for guests visiting the wellness centers depends on the hotel type in which the wellness center is. It is evident that the primary reason at the spa hotels is using the wellness center, no matter whether the reason of visiting the hotel is a medical treatment, or the health improvement. Considering the traditional practice of the medical treatment and the medical care at the spa hotels, these facts are not surprising and confirm the hypothesis 2 . The rest and relaxation are the primary reasons for visiting the other three hotel types (mountain, city and beach). Still, there is some number of those who visit the beach type of the hotel because of the medical treatment, which is, obviously, the wave therapy. The smallest number of users chose the care and beauty treatments and those are the users who visit the wellness centers at the city hotels.

Table 2. The primary reason for guests visiting the wellness centers

\begin{tabular}{|c|c|c|c|c|c|c|}
\hline & \multicolumn{4}{|c|}{ Hotel type } & \multirow{2}{*}{ Total } \\
\hline & & Spa & Mountain & City & Beach & \\
\hline \multirow{3}{*}{$\begin{array}{l}\text { The primary } \\
\text { reason for guests } \\
\text { visiting the } \\
\text { wellness centers }\end{array}$} & medical treatment, health improvement & 15 & 5 & 6 & 9 & 35 \\
\hline & rest and relaxation & 9 & 19 & 14 & 16 & 58 \\
\hline & care and beauty treatments & 1 & 1 & 5 & 0 & 7 \\
\hline \multicolumn{2}{|l|}{ Total } & 25 & 25 & 25 & 25 & 100 \\
\hline
\end{tabular}

\section{The results of the T-test}

The T-test of the independent samples was carried out with the goal of comparing the arithmetic average of the answers between the male and the female respondents (Table 3).

Table 3. T-test according to gender (healthy-living status)

\begin{tabular}{|l|r|r|r|}
\hline \multirow{2}{*}{ Factor } & \multicolumn{2}{|c|}{ Mean } & \multicolumn{2}{c|}{$\mathrm{t}$} \\
\cline { 2 - 3 } & Male $(\mathbf{n}=\mathbf{5 4})$ & Female $(\mathbf{n = 4 6})$ & $-0,905$ \\
\hline Exercise & 3,3565 & 3,5435 & $-3,860 * *$ \\
\hline Diet & 3,1644 & 3,7582 & 1,107 \\
\hline Alcohol & 3,7222 & 3,4783 & 0,518 \\
\hline Smoking & 3,3148 & 3,1739 & 0,711 \\
\hline Stress & 3,4444 & 3,3261 & $-3,906 * *$ \\
\hline Safety & 4,6204 & 4,9348 & \\
\hline *** $p<0,01$ & & &
\end{tabular}

Thanks to the analysis of the results, it could be concluded that there are statistically significant differences in the answers of the respondents according to their sex in the second and in the sixth factor on the level of significance $\mathrm{p}<\mathrm{O}$, OI. The difference is in the fact that the female persons give higher marks to the questions about "diet" and "security". This information shows that the women who use the wellness centers take care of the healthy food more than the men take care. The same situation is with the security factor, especially 
because of the questions within this factor that were connected to the security during driving, which confirms the well-known fact that women are more careful drivers.

The T-test of the independent samples was also carried out with the goal of comparing the significance of the answers between the male and the female respondents about the motives for the visiting (Table 4).

Table 4. T-test according to gender (motives)

\begin{tabular}{|l|r|r|r|}
\hline \multirow{2}{*}{ Factor } & \multicolumn{2}{|c|}{ Mean } & \multicolumn{2}{c|}{$\mathrm{t}$} \\
\cline { 2 - 3 } & Male $(\mathbf{n}=54)$ & Female $(\mathbf{n}=46)$ & $-0,102$ \\
\hline Recreation & 3,8704 & 3,8913 & $-1,954$ \\
\hline Relaxation & 3,9630 & 4,3261 & $-1,167$ \\
\hline Quality of life & 4,1481 & 4,3478 & $-0,057$ \\
\hline Social activity & 3,9444 & 3,9565 & $-1,033$ \\
\hline Curiosity & 2,9815 & 3,2391 & $-0,557$ \\
\hline Experiencing nature & 3,5926 & 3,7174 & $-0,722$ \\
\hline Physical therapy & 3,2593 & 3,4348 & $-1,728$ \\
\hline Health consciousness & 3,9630 & 4,2826 & $-0,338$ \\
\hline Mental therapy & 3,5741 & 3,6522 & $-1,557$ \\
\hline Affordable activity & 2,5741 & 2,9783 & $-0,088$ \\
\hline Pursuing multiactivities & 3,4815 & 3,5000 & $-2,538 *$ \\
\hline Effortless activity & 4,1111 & 4,5435 & 0,030 \\
\hline Meditation & 3,3333 & 3,3261 & \\
\hline
\end{tabular}

${ }^{*} p<0,05$

Thank to the analysis of the results, it could be concluded that there are statistically significant differences in the answers of the respondents according to their sex about the motive "The effortless activities" on the level of significance $\mathrm{p}<\mathrm{O}$, 05. The difference is in the fact that the female persons give significantly higher marks to the questions about the motive "The effortless activities". This motive gets the highest average mark given by both the male and the female respondents. Nevertheless, the women are more explicit than the men are about the motivation for visiting the wellness centers, the desire to free themselves from any effort doing absolutely nothing. With the other motives, there is not noticed any bigger significance between the answers of the male and the female respondents.

\section{The results of the analysis of the variant „Anova"}

The analysis of the variant "Anova" questions if there is a statistically significant connection between the dependant variables (the questions about the habits of the healthy food and the visiting motives) and the independent variables (the socio-demographic characteristics of the examinees). The independent variables in this analysis are: the age, the profession and the amount of the monthly incomes of the respondents.

The results of the one-way analysis variant for the healthy life style domain show that on the level of significance $\mathrm{p}<\mathrm{O}$,OI, there are statistically significant differences between the different age groups about the exercise factor, and on the level of significance $\mathrm{p}<\mathrm{O}, 05$ about the security factor. In order to find out where the significant difference is between the different age groups, the LSD post-hoc test was carried out (Table 5). 
Table 5. The analysis of the variant "Anova" according to age (healthy-living status)

\begin{tabular}{|c|c|c|c|c|c|c|}
\hline \multirow{2}{*}{ Factor } & \multicolumn{4}{|c|}{ Age categories } & \multirow{2}{*}{$\mathrm{F}$} & \multirow{2}{*}{$\begin{array}{l}\text { LSD post- } \\
\text { hoc test }\end{array}$} \\
\hline & Group 1: up to 20 & Group 2: 21-40 & Group 3: 41-60 & Group 4: more than 60 & & \\
\hline Exercise & 4,4375 & 3,2950 & 3,6797 & 2,6250 & $6,407 * *$ & $1>2,3,4$ \\
\hline Diet & 3,8438 & 3,2950 & 3,5039 & 3,6125 & 1,401 & \\
\hline Alcohol & 3,8750 & 3,6000 & 3,4531 & 3,9500 & 0,685 & \\
\hline Smoking & 2,8125 & 3,0600 & 3,4219 & 4,0000 & 1,857 & \\
\hline Stress & 3,6875 & 3,4500 & 3,3281 & 3,0500 & 1,056 & \\
\hline Safety & 4,9375 & 4,6900 & 4,9063 & 4,5500 & $3,121 *$ & $1,3>2,4$ \\
\hline
\end{tabular}

${ }^{*} p<0,05 ;{ }^{* *} p<0,01$

The results of the post-hoc test show that the youngest respondents (2O years old and younger) have the most developed habit of doing some physical activities in everyday life opposite to the other respondents. The same situation is with the security factor: again, younger respondents, and those from the third group, give higher marks for taking care of the personal security and protection.

In the domain of the visiting motive, there is a significant difference between the answers of the respondents of the different age about the two motives: the recreation and the consciousness about good health on the level of significance $p<0$, oI (Table 6). Namely, again the youngest respondents (2O years old and younger) give significantly different answers from the other groups when the recreation motive is in question, which is in agreement with the previous analysis where it is confirmed that the youngest respondents most do everyday physical activities. This fact confirms at the same time the hypothesis 3 . When the motive about the consciousness of the importance of the good health is in question, the eldest group (above 6o years old) separates from the other age groups, especially from the first and the second ones. This tells us that older people are more conscious of the fact how important the good health is and that is the reason why they are motivated to come to a wellness center,

Table 6. The analysis of the variant "Anova" according to age (motives)

\begin{tabular}{|c|c|c|c|c|c|c|}
\hline \multirow[b]{2}{*}{ Motives } & \multicolumn{4}{|c|}{ Age categories } & \multirow[b]{2}{*}{$F$} & \multirow{2}{*}{$\begin{array}{l}\text { LSD post- } \\
\text { hoc test }\end{array}$} \\
\hline & $\begin{array}{l}\text { Group 1: } \\
\text { up to } 20\end{array}$ & Group 2: 21-40 & Group 3: 41-60 & $\begin{array}{c}\text { Group 4: } \\
\text { more than } 60\end{array}$ & & \\
\hline Recreation & 4,7500 & 4,0800 & 3,5000 & 3,4000 & $5,473 * *$ & $1>3,4$ \\
\hline Relaxation & 4,7500 & 4,0600 & 4,2500 & 3,6000 & 2,612 & \\
\hline Quality of life & 4,3750 & 4,2000 & 4,2188 & 4,4000 & 0,221 & \\
\hline Social activity & 4,3750 & 4,0600 & 3,6875 & 3,9000 & 1,286 & \\
\hline Curiosity & 3,2500 & 3,2400 & 2,7500 & 3,4000 & 1,302 & \\
\hline Experiencing nature & 3,7500 & 3,3600 & 3,9063 & 4,2000 & 2,657 & \\
\hline Physical therapy & 3,7500 & 3,1600 & 3,2813 & 4,1000 & 2,089 & \\
\hline Health consciousness & 3,5000 & 3,9400 & 4,2813 & 4,9000 & $5,004 * *$ & $4>1,2$ \\
\hline Mental therapy & 3,5000 & 3,6200 & 3,4375 & 4,2000 & 1,159 & \\
\hline Affordable activity & 2,7500 & 2,4400 & 3,0625 & 3,4000 & 2,490 & \\
\hline Pursuing multiactivities & 3,7500 & 3,4000 & 3,6250 & 3,3000 & 0,565 & \\
\hline Effortless activity & 4,7500 & 4,1800 & 4,4375 & 4,2000 & 1,342 & \\
\hline Meditation & 4,0000 & 3,1000 & 3,5625 & 3,2000 & 2,003 & \\
\hline
\end{tabular}

${ }^{* *} p<0,01$ 
while young people, not thinking much about this fact, but still having the youthful energy, do more recreation than the older ones.

There are some statistically significant differences on the level of significance $p<0$, OI only at the exercise factor about the question of the healthy life style habits concerning the profession of the respondents. The result of the post-hoc test shows that the retired people use less energy for doing everyday physical activities than the other groups, which is in accordance with the analysis of the age categories, where we concluded that the people older than 60 give lower marks to this factor.

Table 7. The analysis of the variant "Anova" according to operating status (healthy-living status)

\begin{tabular}{|c|c|c|c|c|c|c|}
\hline \multirow{2}{*}{ Factor } & \multicolumn{4}{|c|}{ Operating status } & \multirow{2}{*}{$\mathrm{F}$} & \multirow{2}{*}{$\begin{array}{l}\text { LSD post- } \\
\text { hoc test }\end{array}$} \\
\hline & Group 1: student & Group 2: employed & Group 3: unemployed & Group 4: pensioner & & \\
\hline Exercise & 3,6161 & 3,4286 & 4,0000 & 2,6875 & $5,063^{* *}$ & $4<1,2,3$ \\
\hline Diet & 3,3304 & 3,5714 & 3,3929 & 3,3125 & 0,666 & \\
\hline Alcohol & 3,8929 & 3,4762 & 3,7857 & 3,3125 & 1,348 & \\
\hline Smoking & 2,8393 & 3,2738 & 3,5357 & 3,6563 & 1,585 & \\
\hline Stress & 3,5000 & 3,4286 & 3,3214 & 3,1563 & 0,646 & \\
\hline Safety & 4,6786 & 4,7976 & 5,0000 & 4,6250 & 2,540 & \\
\hline
\end{tabular}

${ }^{* *} p<0,01$

On the other hand, we could analyze the significance of the different answers of the people of different professions on the question about the motive of visiting the wellness centers. It could be concluded that there are the significant statistic differences about the motives of the social activities and of the shopping of health products on the level of significance $\mathrm{p}<$ $\mathrm{O}$,OI, and about the motives of the curiosity and the meditation on the level of significance $\mathrm{p}<\mathrm{O}, \mathrm{O} 5$ (Table 8).

Table 8. The analysis of the variant "Anova" according to operating status (motives)

\begin{tabular}{|c|c|c|c|c|c|c|}
\hline \multirow[b]{2}{*}{ Motives } & \multicolumn{4}{|c|}{ Operating status } & \multirow[b]{2}{*}{$\mathrm{F}$} & \multirow{2}{*}{$\begin{array}{l}\text { LSD post- } \\
\text { hoc test }\end{array}$} \\
\hline & $\begin{array}{l}\text { Group 1: } \\
\text { student }\end{array}$ & $\begin{array}{l}\text { Group 2: } \\
\text { employed }\end{array}$ & $\begin{array}{c}\text { Group 3: } \\
\text { unemployed }\end{array}$ & $\begin{array}{l}\text { Group 4: } \\
\text { pensioner }\end{array}$ & & \\
\hline Recreation & 4,2143 & 3,8571 & 3,7857 & 3,4375 & 2133 & \\
\hline Relaxation & 4,0000 & 4,3095 & 4,2857 & 3,7500 & 1729 & \\
\hline Quality of life & 4,1429 & 4,1905 & 4,6429 & 4,1875 & 1235 & \\
\hline Social activity & 4,2143 & 3,5714 & 4,7143 & 3,8125 & $5584 * *$ & $3>2,4$ \\
\hline Curiosity & 3,1071 & 2,8333 & 4,0000 & 3,0000 & $3347^{*}$ & $3>1,2,4$ \\
\hline Experiencing nature & 3,5000 & 3,5238 & 3,8571 & 4,0625 & 1252 & \\
\hline Physical therapy & 3,1071 & 3,2381 & 3,4286 & 3,9375 & 1821 & \\
\hline Health consciousness & 3,8571 & 4,0476 & 4,2857 & 4,5625 & 2261 & \\
\hline Mental therapy & 3,5000 & 3,6190 & 3,2857 & 4,0625 & 1306 & \\
\hline Affordable activity & 2,1071 & 2,7857 & 3,3571 & 3,3125 & $4773^{* *}$ & $1<2,3,4$ \\
\hline Pursuing multiactivities & 3,2857 & 3,5000 & 3,9286 & 3,4375 & 1191 & \\
\hline Effortless activity & 4,2143 & 4,3333 & 4,7143 & 4,0625 & 1580 & \\
\hline Meditation & 2,8929 & 3,4286 & 3,9286 & 3,3125 & $2709 *$ & $1<3$ \\
\hline
\end{tabular}

${ }^{*} p<0,05$; ${ }^{*} p<0,01$ 
The result of the post-hoc test shows that the unemployed people are more motivated than the other groups to come to the wellness centers because of the social activities and the learning new things. On the other hand, students are less interested than the other groups in the shopping of health products and the meditation. Therefore, since the difference in the answers concerning the motive of the mental therapy did not prove as the significant one, and since the meditation did not set apart the group of the business people, we could conclude that the hypothesis 4 is not confirmed.

We can give similar conclusions if we apply this analysis on the different groups of people with the different monthly incomes. And we can see that the people with the lowest incomes (50o€ or less) have the stronger motives for coming to the wellness centers such as the social activities and the learning of the new things, which is more significant than with the people who have higher incomes (Table 9).

Table 9. The analysis of the variant "Anova" according to amount of monthly salaries (motives)

\begin{tabular}{|c|c|c|c|c|c|}
\hline \multirow[t]{2}{*}{ Motives } & \multicolumn{3}{|c|}{ Amount of monthly salaries } & \multirow[t]{2}{*}{$\mathrm{F}$} & \multirow{2}{*}{$\begin{array}{l}\text { LSD post- } \\
\text { hoc test }\end{array}$} \\
\hline & Group 1: up to $500 €$ & Group 2: $501-1000 €$ & Group 3: more than $1000 €$ & & \\
\hline Recreation & 4,1351 & 3,7209 & 3,7500 & 1,884 & \\
\hline Relaxation & 4,2432 & 4,0465 & 4,1000 & 0,444 & \\
\hline Quality of life & 4,2973 & 4,2093 & 4,2000 & 0,131 & \\
\hline Social activity & 4,3784 & 3,8140 & 3,4500 & $6,218^{* *}$ & $1>2,3$ \\
\hline Curiosity & 3,5405 & 2,9302 & 2,6500 & $4,304 *$ & $1>2,3$ \\
\hline Experiencing nature & 3,7838 & 3,5349 & 3,6500 & 0,492 & \\
\hline Physical therapy & 3,4324 & 3,2558 & 3,3500 & 0,210 & \\
\hline Health consciousness & 4,0270 & 4,1163 & 4,2500 & 0,369 & \\
\hline Mental therapy & 3,3784 & 3,8605 & 3,5000 & 1,913 & \\
\hline Affordable activity & 2,6486 & 2,9070 & 2,6500 & 0,474 & \\
\hline Pursuing multiactivities & 3,6486 & 3,5116 & 3,1500 & 1,497 & \\
\hline Effortless activity & 4,2973 & 4,2791 & 4,4000 & 0,135 & \\
\hline Meditation & 3,3784 & 3,2326 & 3,4500 & 0,276 & \\
\hline
\end{tabular}

${ }^{*} p<0,05 ;{ }^{* *} p<0,01$

\section{Conclusion}

The wellness tourism can be characterized as an old-new branch of the tourism. It is old because of the inseparable connection to the spa tourism and the ancient origin of the treatments that are used even nowadays, and some of them originated from the $\mathrm{BC}$ period. It is new because of the contemporary innovations in the field, as well as the new point of view on the wellness philosophy and the different needs of the modern man.

Besides the inner urge of the wellness tourists, their motivation for coming to a wellness center also depends on the size and on the variety of the offers of the wellness centers, which are a kind of an attraction factor. This research was carried out on the territory of Slovenia that was chosen as a very developed wellness destination with the rich and developed wellness offers. 
The causes of this research are the motives of the wellness users in the chosen hotels in Slovenia, and the starting point for defining this theme is the theory of the tourist motivation. The majority of the authors agree that the tourist motive is actually the combination of the need and the subject of that need, i.e., the inner urge and the outer charm. In addition, when the types of the motives are in question, they can be various: physical, cultural, interpersonal, prestige etc.

Based on the previous researches on the theme of the motivation of the wellness tourists, and based on some logical assumptions (about the territorial and demographic characteristics) at the beginning of this research, four hypotheses were assumed, and only one was not confirmed.

The assumption was that the motives of the users of the wellness centers depended a lot on their life style, i.e. their everyday habits connected to their healthy life. That is why the behavior to their health was established first, and the reasons for coming were established later.

The results of the research show that there are certain differences in the answers of the respondents depending on the groups they belong, such as the sex, the age, the profession, the incomes. Therefore, the motive of the effortless activities (doing nothing) is stronger with the women than with the men, while the recreation motive is the strongest with the younger people, who are 20 or less. In addition, it is proved that the people with the lowest incomes are more motivated with the possibility to socialize and to learn new things than the people with higher incomes are.

When we sum up all these results, we can conclude that the motives for visiting the wellness centers at the hotels in Slovenia are numerous and they depend a lot on the everyday healthy life style of the visitors. In addition, they depend on many other factors connected to the socio-demographic characteristics of the visitors, or on the characteristics of the wellness centers. This information should be used more often in the future researches of this kind because it is very important for discovering the needs of the wellness tourists and for meeting their needs.

\section{References}

Azman, I., Chan, J. (2OIO). Health and Spa Tourism Business: Tourists' Profiles and Motivational Factors. Internet: www.ttraeuropeconference.com (O8.II.2OI2).

Ažman Momirski, L., Kladnik, D. (2009). Terraced landscapes in Slovenia. Acta geographica Slovenica 49-I. Ljubljana.

Bansal, H., Eiselt, H. A. (2OO4). Exploratory research of tourist motivations and planning. Tourism Management 25, 387-396.

Blešić, I., Wallranbestein, K., Dević, M. (2008). Motivation of Novi Sad (Vojvodina, Serbia) visitors out of the tourist season. Geographica Pannonica I2-I, Novi Sad.

Blešić, I., Pivac, T., Stamenković, I., Besermenji, S. (2OI3). Motives of Visits to Ethno Music Festivals with Regard to Gender and Age Structure of Visitors. Event Management, Vol. I7. USA.

González, A. M., Bello, L. (2002). The construct "lifestyle" in market segmentation. European Journal of Marketing 36-I/2, 5I-85. 
Kim, B., Batra, A. (2000). Healthy-living Behavior Status and Motivational Characteristics of Foreign Tourists to Visit Wellness Facilities in Bangkok. Graduate School of Business, Assumption University, Bangkok.

Mak, A. H. N., Wong, K. K. F. (2007). Motivation of Hong Kong residents seeking spa experiences when travelling away from Hong Kong. Proceedings of 5th Asia-Pacific CHRIE and I3th Asia-Pacific Tourism Association Joint Conference 2007.

McNeil, K. R., Ragins, E. J. (2005). Staying in the spa marketing game: trends, challenges, strategies and techniques. Journal of Vacation Marketing, II(I), 3I-39.

Muller, H., Lanz-Kaufmann, E. (2OOI). Wellness Tourism: Market analysis of special health tourism segment and implications for the hotel industry. Journal of Vacation Marketing, 7(I), 5-I7.

Mugomba \& Caballero, D. (2006). Medical Tourism and its Entrepreneurial OpportunitiesA conceptual framework for entry into the industry. Master Thesis. School of Business Gotheborg University.

Page, S. J., Connell, J. (2006). Tourism a modern synthesis, 2nd edition, Thomson London. Puczk, L., Bachvarov, M. (2006). Spa, Bath, Thermae: What's Behind the Labels?. Tourism Recreation Research, 3I(I), 83-9I.

Ritter, S. (2005). Tourism for wellness: Trends and skill needs in tourism. Retrieve October 6, 2008, from http://www.cedefop.europa.eu/etv/Upload/Information_resources/ Bookshop/4I3/5I6I_en.pdf

Yoon, Y., Uysal, M. (2005). An examination of the effects of motivation and satisfaction on destination loyalty: a structural model. Tourism Management 26, 45-56. 